\title{
CARBON MONOXIDE TREND IN THE CITY OF RIO DE JANEIRO VIA MANN-KENDALL AND CUSUM TESTS
}

\author{
TENDÊNCIAS DE MONÓXIDO DE CARBONO NA CIDADE DO RIO DE JANEIRO \\ VIA TESTES DE MANN-KENDALL E SOCOM
}

\begin{abstract}
Givanildo de GOIS ${ }^{1}$; José Francisco de OLIVEIRA-JUNIOR ${ }^{2}$; Elania Barros Da SILVA ${ }^{3}$; Juliana Lúcio Motta MAIA ${ }^{4}$ Indira Sueline Silva ALELUIA ${ }^{5}$; Paulo Eduardo TEODORO ${ }^{6^{*}}$

1. Escola de Engenharia Industrial Metalúrgica de Volta Redonda, Centro Tecnológico, Universidade Federal Fluminense, Volta Redonda, RJ, Brasil; 2. Instituto de Ciências Atmosféricas (ICAT), Universidade Federal de Alagoas, Maceió, AL, Brasil; 3. Secretaria Municipal de Saúde de Capela, Capela, AL, Brasil; 4. Universidade Federal Fluminense, Niterói, RJ, Brasil; 5. Instituto de Matemática (IM), Universidade Federal de Alagoas, Maceió, AL, Brasil; Universidade Federal de Mato Grosso do Sul, Chapadão do Sul, MS, Brasil.eduteodoro@hotmail.com
\end{abstract}

\begin{abstract}
Hourly mean concentrations of carbon monoxide trend (CO) in the city of Rio de Janeiro (CRJ) was evaluated based on statistical tests. Air quality stations used were: Central, Copacabana, São Cristóvão and Tijuca from 2010 to 2014. The results of the CO trend based on the Mann-Kendall (MK) test showed an inverse correlation with time, with significant decrease in all seasons. Significant increase trend $(Z>0)$ and p-value $<0.05$ were recorded in Centro and Tijuca in 2010 and 2012 with magnitude between 0.0224 and $0.0067 \mathrm{ppm} /$ year. Insignificant increase occurred only in São Cristóvão (2011) for positive values $(\mathrm{Z}>0)$ and p-value $>0.05$. CUSUM test showed that $Q$ magnitude did not exceed the critical value at $1 \%$ and $5 \%$ probability levels. Cumulative Sum Test (CUSUM) showed homogeneous and significant CO concentrations. Significant abrupt changes occurred in the months of May, June, July, August and September and insignificant in January, February, June, August and November at 1\% and 5\% probability. CO concentrations occurred in the predominant directions North-Northwest (NNW), South-Southwest (SSW) and South-west (SW). Both sectors are influenced by the main synoptic systems (Frontal System and South Atlantic Subtropical High) that act on CRJ. MK and CUSUM tests proved to be efficient in evaluating trends and abrupt changes in CO concentrations and air quality stations in the CRJ.
\end{abstract}

KEYWORDS: Emissions. Pollutants. Statistical tests. Air quality.

\section{INTRODUCTION}

In the last decades, air pollution and air quality in large urban and industrial centers are a serious social and environmental problem around the world (GUERRERO et al. 2012; ZERI et al., 2016). Atmospheric pollutants are influenced directly by meteorological conditions, topographic features along with local, mesoscale and synoptic meteorological systems (OLIVEIRA JÚNIOR et al., 2010; ZERI et al., 2011).

In Brazil, important advances have been made in environmental legislation through federal resolutions, such as the CONAMA $n^{\circ} 03 / 90$ resolution (CONAMA 03/90, 1990). It aims to regulate the levels of air pollutants that can be monitored and controlled in the country and have contributed to minimize the effects of air pollution and air quality in metropolitan regions (MR) (FREITAS et al, 2009; ZERI et al, 2016), mainly environmental degradation (GOULART et al., 2015) and respiratory and cardiac problems faced by society (CARVALHO et al., 2015).

MR of the Rio de Janeiro (MRRJ) daily record high levels of carbon monoxide (CO) concentration, caused by emissions from motor vehicles (CONAMA 08/90, 1990 resolution) associated with conditions of thermal inversion, periods of calm and droughts (FREITAS et al., 2009; OLIVEIRA JÚNIOR et al., 2010; PIMENTEL et al., 2014). Currently, the MRRJ has been facing several problems related to high $\mathrm{CO}$ concentrations that have been routinely detected through air quality stations (INEA, 2010; LYRA et al., 2011; ZERI et al., 2011) and/or by the application of analytical models of atmospheric diffusion or air quality regulators (GUERRERO et al. 2012; CUNHA et al., 2009; SOARES et al., 2014).

Recently, several studies have been carried out in the CRJ and MRRJ. Soares et al. (2014) carried out a study comparing the main regulatory models in the literature, AERMOD (American Meteorology Society-Environmental Protection Agency Regulatory Model) and CALPUFF (California Puff Model) in the Air Basin III with emphasis on sulfur dioxide $\left(\mathrm{SO}_{2}\right)$. Lyra et al. (2011) evaluated particulate matter $\left(\mathrm{PM}_{10}\right)$ in CRJ based on the application of linear models. However, until now no study has been performed based on 
parametric and nonparametric tests applied in a time series of a pollutant concentration in the CRJ.

Thus, the study aimed to evaluate increase or decrease trends of $\mathrm{CO}$ concentration in $\mathrm{CRJ}$ based on non-parametric (Mann-Kendall-MK) and parametric tests (CUSUM) and meteorological data.

\section{MATERIAL AND METHODS}

The city of Rio de Janeiro (CRJ) is located in the southeast region of Brazil, between latitudes $22^{\circ} 45^{\prime} 05^{\prime} \mathrm{S}$ and $23^{\circ} 04^{\prime} 10^{\prime \prime} \mathrm{S}$ and longitudes $43^{\circ} 06^{\prime} 30^{\prime \prime} \mathrm{W}$ and $43^{\circ} 47^{\prime} 40^{\prime \prime} \mathrm{W}$. According to the Köppen's classification, the city's climate is of the kind "Aw", characterized by dry and cool winters and wet and rainy summers. Air temperature ranges from $21.1^{\circ} \mathrm{C}$ (average minimum temperatures) during winter to $27.3^{\circ} \mathrm{C}$ (average maximum temperatures) during summer. The annual average temperature is $23.9^{\circ} \mathrm{C}$, rainfall is approximately $1,258 \mathrm{~mm}$ year $^{-1}$ and the average number of days with rainfall is 124 (ZERI et al., 2011).

CRJ presents remnants areas of the Atlantic Forest domain, mostly protected by laws, mainly under Conservation Units (UC) (GOULART et al., 2015). In the last decades, we observed a territorial and urban expansion in the CRJ, accompanied by the increased number of formal and informal civil buildings. According to IBGE (2016), the city had an increase of approximately 840,000 inhabitants between 1991 and 2010, which represented 15\% in this period.

Hourly mean carbon monoxide (CO) and meteorological (wind) concentrations belonging to the Municipal Environmental Department (SMAC) from 2010 to 2014 were used to determine the increase or decrease trend in the $\mathrm{CO}$ concentration at some air quality stations (Central, Copacabana, São Cristóvão and Tijuca) existing in CRJ (INEA, 2010). From R software version 3.1.2 (R Core Team, 2015), Mann-Kendall (MK) non-parametric test (MANN, 1945; KENDALL, 1975) was applied to $\mathrm{CO}$ concentrations from the respective air quality stations.

The test considers that, in the case of stability of a time series, the values succession occurs independently and the probability distribution must always remain the same (simple random series). Back (2001) states that the MK test is the most appropriate method for the location and approximate detection of the starting point of a given trend. MK test is widely used based on the interdependence between two variables, in the case of time series (rainfall, air temperature, hot spots among others), in one of them, the time is known (LÁZARO et al., 2001; CAÚLA et al., 2016).

In a second step, we calculated estimates of the trend magnitudes of $\mathrm{CO}$ concentrations in the four air quality seasons by $S_{e}$ curvature inclination, in which it is more robust than the angular coefficient of the equation of the line obtained using the linear regression method, since it can deviate much from the true value of the line inclination (Ferrari et al., 2012) if there are extreme values of $\mathrm{CO}$ concentration.

Then, we applied the Cumulative Sums test (CUSUM) proposed by Buishand (1982) and suggested by the World Meteorological Organization (WMO). CUSUM is a parametric test that allows identifying the period (month or year) of the beginning a probable abrupt change in the carbon monoxide (CO) concentration. This method tests whether the means in two parts from a data record are different (for an unknown change time), assuming that the data is normally distributed.

$\mathrm{CO}$ emissions violations were assessed according to CONAMA $\mathrm{n}^{\circ} 03 / 90$ resolution (Table 1). Finally, pollution roses of the $\mathrm{CO}$ concentration were made through the WRPLOT software version 7.0.0 (WRPLOT, 2015), based on the CUSUM test result.

Table 1. Air Quality Standards according to CONAMA n 03/90 Resolution.

$$
\text { Pollutant Sampling Time Primary/Secondary Standards }\left(\mu \mathrm{g} / \mathrm{m}^{3}\right)
$$

\begin{tabular}{ccc}
\hline \multirow{2}{*}{$\mathrm{CO}$} & 1 hour & $40000(35 \mathrm{ppm})$ \\
& 8 hours & $10000(9 \mathrm{ppm})$ \\
\hline
\end{tabular}

Source: INEA (2010). 


\section{RESULTS AND DISCUSSION}

The results for the trend and detection of the abrupt changes periods in $\mathrm{CO}$ concentration in the air quality stations in the CRJ are shown in Table 2. MK test showed that the $\mathrm{CO}$ concentration is inversely correlated with time. There is a significant decrease trend with the $S_{e}$ magnitude sometimes significant now insignificant to $\mathrm{Z}<0$ and $\mathrm{p}$-value $<$ or $>0.05$, this is, over the years passed the $\mathrm{CO}$ concentration decreased significantly in all the air quality stations in the CRJ from $-0,0000$ to $-0,0162$ ppm/year

The Program for the Control of Air Pollution by Automotive Vehicles (PROCONVE), created in 1986, aims to reduce atmospheric pollution caused by mobile sources, by means of staggered fixing the maximum emission limits for light new vehicles (Otto and Diesel cycles) and heavy vehicles (buses and trucks of the Diesel cycle) besides specification of fuel quality (CONAMA $\mathrm{n}^{\circ}$ 08/90 resolution, 1990; FEEMA, 2004). It is noteworthy that in this study period there was a reduction in the $\mathrm{CO}$ concentration, followed by the increased vehicular fleet in Brazil, which in turn underwent a series of transformations, mainly in the change of the motors of the automobiles that happened to be flex, interfering in the $\mathrm{CO}$ pollutant concentrations.

Table 2. Statistical analysis (Z, MK, p-value, $S_{e}$, CUSUM and Q) of the CO concentrations at air quality stations (Central, Copacabana, São Cristóvão and Tijuca) in the CRJ from 2010-2014.

\begin{tabular}{|c|c|c|c|c|c|c|c|}
\hline Stations & Years & $\mathbf{Z}$ & MK (ppm/year) & P-value & $\begin{array}{c}S_{e} \\
\text { (ppm/year) }\end{array}$ & CUSUM & $\mathbf{Q}$ \\
\hline \multirow{5}{*}{ CENTRAL } & 2010 & 7.19 & 0.25 & 0.0000 & $0.0224^{\mathrm{s}}$ & JUN & $0.16^{\mathrm{s}}$ \\
\hline & 2011 & -0.65 & -0.02 & 0.5149 & $-0.0014^{\mathrm{I}}$ & JAN & $0.13^{\mathrm{s}}$ \\
\hline & 2012 & -3.76 & -0.13 & 0.0002 & $-0.0102^{\mathrm{S}}$ & SEP & $0.09^{\mathrm{S}}$ \\
\hline & 2013 & -2.84 & -0.10 & 0.0045 & $-0.0057^{\mathrm{S}}$ & AUG & $0.10^{\mathrm{S}}$ \\
\hline & 2014 & -8.58 & -0.30 & 0.0000 & $-0.0162^{\mathrm{S}}$ & AUG & $0.09^{\mathrm{S}}$ \\
\hline \multirow{5}{*}{ COPACABANA } & 2010 & -6.57 & -0.23 & 0.0000 & $-0.0122^{\mathrm{S}}$ & SEP & $0.09^{\mathrm{S}}$ \\
\hline & 2011 & -1.63 & -0.06 & 0.1043 & $-0.0025^{\mathrm{I}}$ & AUG & $0.09^{\mathrm{S}}$ \\
\hline & 2012 & -0.04 & 0.00 & 0.9644 & $0.0000^{\mathrm{I}}$ & $\mathrm{NOV}$ & $0.10^{\mathrm{S}}$ \\
\hline & 2013 & -2.85 & -0.10 & 0.0044 & $-0.0037^{\mathrm{s}}$ & SEP & $0.12^{\mathrm{S}}$ \\
\hline & 2014 & -0.75 & -0.03 & 0.4537 & $-0.0011^{\mathrm{I}}$ & FEB & $0.10^{\mathrm{s}}$ \\
\hline \multirow{5}{*}{ SÃO CRISTOVÃO } & 2010 & -5.08 & -0.18 & 0.0000 & $-0.0091^{\mathrm{s}}$ & MAY & $0.14^{\mathrm{s}}$ \\
\hline & 2011 & 0.98 & 0.03 & 0.3262 & $0.0016^{\mathrm{I}}$ & AUG & $0.09^{\mathrm{s}}$ \\
\hline & 2012 & -0.08 & 0.00 & 0.9364 & $-0.0001^{\mathrm{s}}$ & JUL & $0.11^{\mathrm{s}}$ \\
\hline & 2013 & -0.55 & -0.02 & 0.5862 & $-0.0003^{\mathrm{I}}$ & JUN & $0.11^{\mathrm{s}}$ \\
\hline & 2014 & -5.62 & -0.20 & 0.0000 & $-0.0107^{\mathrm{s}}$ & MAY & $0.09^{\mathrm{s}}$ \\
\hline \multirow{5}{*}{ TIJUCA } & 2010 & 10.14 & 0.39 & 0.0000 & $0.0067^{\mathrm{s}}$ & JUL & $0.11^{\mathrm{s}}$ \\
\hline & 2011 & -2.21 & -0.08 & 0.0273 & $-0.0024^{\mathrm{S}}$ & AUG & $0.13^{\mathrm{S}}$ \\
\hline & 2012 & 10.05 & 0.35 & 0.0000 & $0.0288^{\mathrm{S}}$ & JUL & $0.08^{\mathrm{S}}$ \\
\hline & 2013 & -2.26 & -0.08 & 0.0241 & $-0.0036^{\mathrm{s}}$ & AUG & $0.08^{\mathrm{S}}$ \\
\hline & 2014 & -4.65 & -0.16 & 0.0000 & $-0.0078^{\mathrm{s}}$ & MAY & $0.07^{\mathrm{s}}$ \\
\hline
\end{tabular}

S-Significant for P-value $\leq 0.05$ and I-Insignificant for P-value $\geq 0.05$.

There was a significant increase trend in the $\mathrm{CO}$ concentration, for positive values $(\mathrm{Z}>0)$ and $\mathrm{P}$ value $<0.05$ recorded at stations Central and Tijuca in the years 2010 and 2012 with significant $S_{e}$ magnitude from $0.0224 \mathrm{ppm} / \mathrm{year}$ to 0.0067 ppm/year. Unlike, at São Cristóvão station, where there was an insignificant increase in $\mathrm{CO}$ concentration, only in 2011 to positive values $(\mathrm{Z}>$ $0)$ and P-value $>0.05$ followed by a $S_{e}$ magnitude of $-0.0016 \mathrm{ppm} / \mathrm{year}$. However, the Copacabana station was the one that presented a significant decrease trend in $\mathrm{CO}$ concentration, to negative values $(\mathrm{Z}<$
0) and P-value $<0.05$ from 2010 to 2014 with significant to insignificant $S_{e}$ trend from -0.0122 $\mathrm{ppm} /$ year to $-0.0011 \mathrm{ppm} /$ year.

CUSUM test showed that $Q$ magnitude did not exceed the critical value for $1 \%$ and $5 \%$ probability levels, which indicated that the time series of $\mathrm{CO}$ was homogeneous and significant. CUSUM test showed a good agreement with the MK test, which identified significant abrupt changes in the months of May (end of autumn), June, July, August (winter) and September (early spring) and insignificant in January, February (summer), June, 
August (beginning and end of winter) and November (end of spring) and 5\% probability for the mean $\mathrm{CO}$ concentration in most stations of the CRJ.

These months are influenced by meteorological systems of several scales and that interfere drastically in the pollutants concentration of the CRJ (LYRA et al., 2010; ZERI et al., 2011). The main conditions for increased pollutants concentrations in CRJ are associated with orographic complexity, turbulence levels, prevailing winds regime, mesoscale circulation and the South Atlantic Subtropical High (SASH) positioning, associated to the displacement of frontal systems (FS) (ZERI et al., 2011; PIMENTEL et al., 2014 and SOARES et al., 2014).

Table 3 shows the evolution of the number of violations of the air quality standards for $\mathrm{CO}$ concentrations in the study period for the stations belonging to the SMAC, comparing the estimates of the values of the concentrations at 1 hour and 8 hours with the standards primary and secondary established by CONAMA n ${ }^{\circ}$ 03/90 resolution (Table 1). Sampling time at 1 hour for the primary and secondary standards no recorded violations at any of the CRJ air quality stations in the study period.
However, for the estimates at 8 hours, the Central station presented a total of 7 violations, followed by the São Cristovão station with 27 violations, and finally the Tijuca station with 2 violations. All stations are close to the main traffic routes of the CRJ, for example, Av. Brasil and Vermelha line and, therefore, a higher concentration of vehicles that contribute actively to the air quality degradation, according to the inventory carried out by INEA (2010). The exception was the Copacabana station with no violation for the primary and secondary standards $\left(10000 \mu \mathrm{g} / \mathrm{m}^{3}\right.$ or 9 ppm) in the study period. Copacabana station is close to a region of coastal environment surrounded by several buildings, perfect conformation for the formatting urban canyons that probably channel the circulation and favor the dispersion of CO (ZERI et al., 2011; PIMENTEL et al., 2014).

The results obtained were corroborated by the study carried out by Cunha et al. (2009) on the vehicular emission in the Air Basin III of the MRRJ by Gaussian model of air quality AERMOD. AERMOD simulations indicated violations in the air quality standards for mean sampling time at 1 hour and 8 hours of 33 violations in a single point and 74 violations at four different points.

Table 3. Numbers of violations of air quality standards according to CONAMA $n^{\circ} 03 / 90$ Resolution ( 1 and 8 hours), from 2010-2014 at air quality stations (Central, Copacabana, Tijuca and São Cristóvão).

\begin{tabular}{cccc}
\hline STATIONS & YEARS & 1 HOUR & 8 HOURS \\
\hline CENTRAL & 2010 & 0 & 4 \\
COPACABANA & 2013 & 0 & 3 \\
& $2010-2014$ & No & No \\
& 2010 & 0 & 7 \\
SÃO CRISTÓVÃO & 2011 & 0 & 4 \\
& 2012 & 0 & 6 \\
TIJUCA & 2013 & 0 & 7 \\
& 2014 & 0 & 3 \\
\hline
\end{tabular}

For understanding the $\mathrm{CO}$ concentration, wind is one of the most important factors, since it transports and disperses atmospheric pollutants and, therefore, allows us to identify the trajectory and reach of the pollutant (OLIVEIRA JÚNIOR et al., 2010; PIMENTEL et al., 2014). From the CUSUM test, information on the abrupt changes in $\mathrm{CO}$ concentration was provided. Based on these results pollution roses were built during the period 20102014.

Figures 1(a) and (b) show the direction of the $\mathrm{CO}$ concentration in the pollution roses for the Center station. In it, the CUSUM test identified abrupt changes in $\mathrm{CO}$ concentration in the months of June and August in 2010 and 2014 and higher CO concentrations predominantly in the North Northwest (NNW) sector of the station. This winter wind pattern diversification is characteristic of the SASH activity (OLIVEIRA JÚNIOR et al., 2010; PIMENTEL et al., 2014). For São Cristóvão (Figure 1(c)) and (d) and Tijuca (Figure 3(e)), CUSUM test and pollution roses revealed abrupt changes in $\mathrm{CO}$ concentration in the months of June 2013 and July 2012, suggesting a strong predominance of CO concentration in the South-South (SSW) and SouthWest (SW) sectors for the São Cristóvão station and 
South-Southwest (SSW) for the Tijuca station. All the identified patterns are typical of FS performance

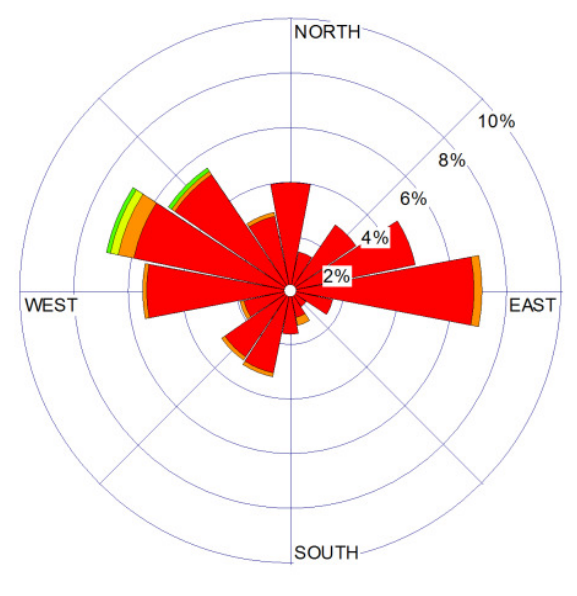

(a)

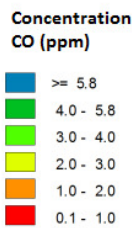

(c)
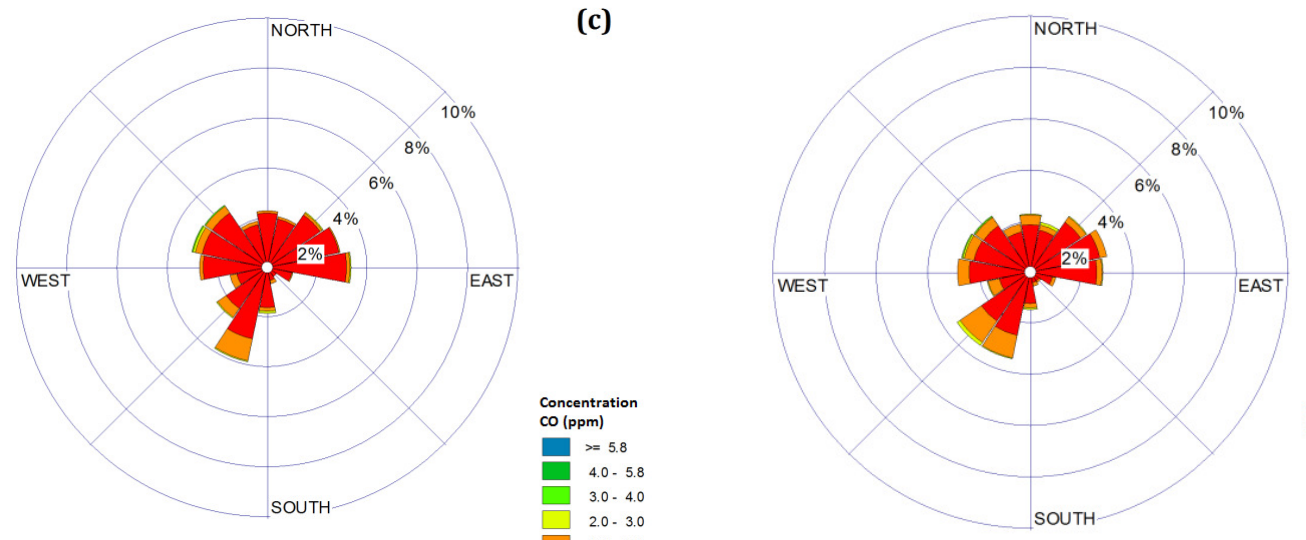

(d)

(b)

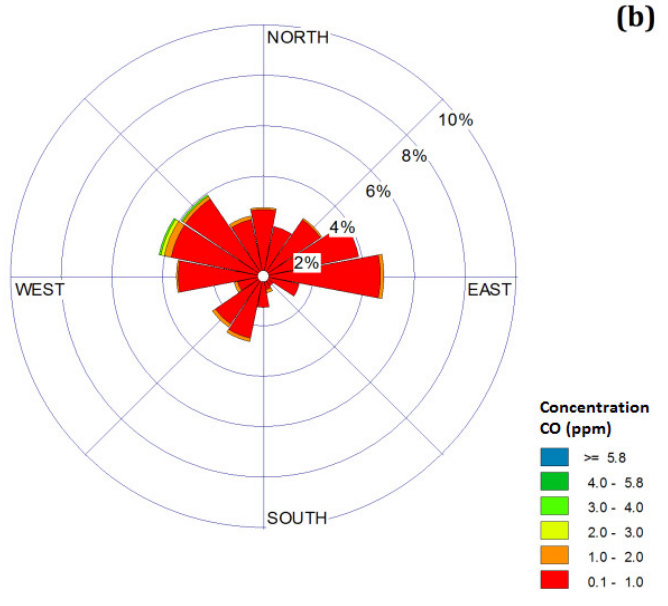

Concentration

CO (ppm)

$\square=5.8$

$4.0-5.8$
$3.0-4.0$

2.0. 3.0

$1.0-2.0$

(e)

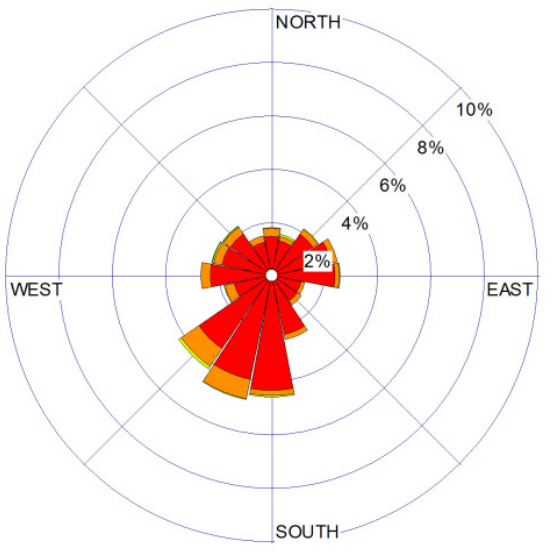

$1.0-2.0$
$0.1-10$

Figure 1. Pollution roses of the CO concentration (ppm) at Central, São Cristóvão and Tijuca stations in the winter from 2010-2014.

\section{CONCLUSIONS}

Mann-Kendall test shows a strong significant and inverse trend over time and with a decreasing in carbon monoxide concentration.
CUSUM test has good agreement with the MannKendall test, identifying significant abrupt changes in late autumn, winter and early spring; and insignificant in the summer, beginning and end of 
winter and late spring at $1 \%$ and $5 \%$ probability level.

All stations are close to the most important traffic routes in the city of Rio de Janeiro, therefore, they actively contribute to the air quality degradation on this scale. Predominant directions of
CO concentrations based on the CUSUM test are in the North-Northwest, South-Southwest and Southwest sectors. All sectors are influenced by the main synoptic systems (FS and SASH) operating in the city of Rio de Janeiro.

RESUMO: Foi avaliada a tendência das concentrações médias horárias de monóxido de carbono (CO), com base em testes estatísticos na cidade do Rio de Janeiro (CRJ). As estações de qualidade do ar utilizadas foram: Centro, Copacabana, São Cristóvão e Tijuca entre os anos de 2010 a 2014. Os resultados da tendência de CO com base no teste de Mann-Kendall (MK) mostrou uma correlação inversa com o tempo, com diminuição significativa em todas as estações. Tendência de aumento significativo $(Z>0)$ e p-valor $<0,05$ foram registradas no Centro e Tijuca nos anos de 2010 e 2012 com magnitude entre 0,0224 a 0,0067 ppm/ano. Aumento insignificante ocorreu apenas em São Cristóvão (2011) para valores positivos $(Z>0)$ e p-valor $>0,05$. O teste de SOCUM mostrou que a magnitude de $Q$ não excedeu o valor crítico aos níveis de $1 \%$ e $5 \%$ de probabilidade. O teste das Somas Cumulativas (SOCUM) mostrou que as concentrações de CO foram homogêneas e significativas. Mudanças bruscas significativas ocorreram nos meses de maio, junho, julho, agosto e setembro e insignificante em janeiro, fevereiro, junho, agosto e novembro a $1 \%$ e $5 \%$ de probabilidade. As concentrações de CO ocorreram nas direções predominantes Norte-Noroeste (NNW), Sul-Sudoeste (SSW) e Sudoeste (SW). Ambos os setores são influenciados pelos principais sistemas sinóticos (Sistema Frontal e Alta Subtropical do Atlântico Sul) que atuam na CRJ. Os testes MK e SOCUM se mostraram eficientes na avaliação das tendências e mudanças bruscas nas concentrações de $\mathrm{CO}$ e nas estações de qualidade do ar existentes na CRJ.

PALAVRAS-CHAVE: Emissões. Poluentes. Testes estatísticos. Qualidade do ar.

\section{REFERENCES}

BACK, A. J. Aplicação de análise estatística para identificação de tendências climáticas. Pesquisa Agropecuária Brasileira, Brasília, v. 36, 717-726, 2001.

BUISHAND, T. A. Some methods for testing the homogeneity of rainfall records. Journal of Hidrology, Stuttgart, v. 58, p. 11-27,1982.

CARVALHO, V. S. B.; FREITAS, E. D.; MARTINS, L. D.; MARTINS, J. A.; MAZZOLI, C. R. R.; ANDRADE, M. F. Air quality status and trends over the Metropolitan Area of São Paulo, Brazil, as a result of emission control policies. Environmental Science \& Policy, Genève, v. 47, p. 68-79, 2015.

CAÚLA, R. H.; OLIVEIRA JÚNIOR, J.F.; GOIS, G.; DELGADO, RC; PIMENTEL, L. C. G.; TEODORO, P. E. Nonparametric statistics applied to fire foci obtained by meteorological satellites and their relationship to the MCD12Q1 product in the state of Rio de Janeiro. Land Degradation \& Development, Malden, v. 25, p. 225$236,2016$.

CONSELHO NACIONAL DE MEIO AMBIENTE. Dispõe sobre padrões de qualidade do ar, previstos no PRONAR. Resolução CONAMA no 03, de 6 de dezembro de 1990. Disponível em $<$ http://www.mma.gov.br/port/conama/>. Acesso em 03/07/2015.

CONSELHO NACIONAL DE MEIO AMBIENTE. Dispõe sobre padrões de qualidade do ar, previstos no PRONAR. Resolução CONAMA no 08, de 6 de dezembro de 1990. Disponível em $<$ http://www.mma.gov.br/port/conama/>. Acesso em 03/07/2015.

CUNHA, B. D.; SILVA, M. S.; VELLOSO, M. F. A.; OLIVEIRA JÚNIOR, J. F.; PIMENTEL, L. C. G. Avaliação do desempenho dos modelos regulatórios de qualidade do ar AERMOD e CALPUFF para a Bacia Áerea III - RJ. Ciência \& Natura, Santa Maria, v. 6, p. 225-227, 2009. 
FEEMA - Fundação Estadual de Engenharia do Meio Ambiente. Inventário de Fontes Emissoras de Poluentes Atmosféricos da Região Metropolitana do Rio de Janeiro. Departamento de Planejamento Ambiental, Divisão de Qualidade do Ar, Rio de Janeiro, RJ - Brasil. 2004.

FERRARI, A. L.; VECHHIA, F. A. S.; COLABONE; R. O. Tendência e variabilidade anuais da temperatura e da pluviosidade em Pirassununga-SP. Revista Brasileira de Climatologia, Curitiba, v. 10, p. 30-46, 2012.

FREITAS, S. R.; LONGO, K.; RODRIGUES, L. F. Modelagem numérica da composição química da atmosfera e seus impactos no tempo, clima e qualidade do ar. Revista Brasileira de Meteorologia, Curitiba, v. 24, n. 2,188-207, 2009.

GOULART, A. C. O.; DELGADO, R. C.; OLIVEIRA JÚNIOR, J. F.; GOIS, G.; OLIVEIRA, E. S. Relação espectro-temporal entre índices de vegetação e a chuva na cidade do Rio de Janeiro. Revista de Ciências Agrárias, Belém, v. 58, n. 3, p. 277-283, 2015.

GUERRERO, J. S. P.; PIMENTEL, L. C. G.; OLIVEIRA JÚNIOR, J. F.; HEILBRON, P. F. L.; ULKE, A. G. A unified analytical solution of the steady-state atmospheric diffusion equation. Atmospheric Environment, Hong Kong, v. 55, p. 201-212, 2012.

INEA - Instituto Estadual do Ambiente. Relatório Anual da Qualidade do Ar do Estado do Rio de Janeiro. Rio de Janeiro, 2009. 108 p. Relatório Técnico. Disponível em:http://www.inea.rj.gov.br/downloads/relatorios/qualidade_ar_2009.pdf Acesso em: 20 jul. 2010.

INSTITUTO BRASILEIRO DE GEOGRAFIA E ESTATÍSTICA - IBGE. Censo Brasileiro. Disponível em: $<$ <ttp://www.ibge.gov.br>. Acesso em: 22 maio 2016.

KENDALL, M. G. Rank correlation methods. London: Charles Griffin, 120p. 1975.

LÁZARO, R.; RODRIGO, F. S.; GUTIÉRREZ, L.; DOMINGO, F.; PUIGDEFÁBREGAS, J. Analysis of a thirty year rainfall record (1967-1997) from semi-arid SE Spain: a plant ecological perspective. Journal of Arid Environments, Chubut, v.48, p. 373-395, 2001.

LYRA, G. B., ODA-SOUZA, M., VIOLA, D. N. Modelos Lineares Aplicados À Estimativa da Concentração do Material Particulado $\left(\mathrm{PM}_{10}\right)$ na Cidade do Rio de Janeiro, RJ. Revista Brasileira de Meteorologia, São José dos Campos, v. 26, p.392 - 400, 2011.

MANN, H. B. Non-parametric test against trend. Econometrika, Malden, v. 13, n. Y, p. 245-259, 1945.

OLIVEIRA JÚNIOR J. F., PIMENTEL L. C. G., LANDAU L. Critérios de estabilidade atmosférica para a região da Central Nuclear Almirante Álvaro Alberto, Angra dos Reis - RJ. Revista Brasileira de Meteorologia, Curitiba, v.25, n. 2, p. 270-285, 2010.

PIMENTEL, L. C. G.; CORREIA E. B.; MARTON E.; CATALDI M., NOGUEIRA, E. Influência dos parâmetros de configuração do modelo CALMET sobre a simulação da circulação atmosférica na região metropolitana do Rio de Janeiro. Revista Brasileira de Meteorologia, Curitiba, v.29, n.4, p. 121-132, 2014.

PIMENTEL, L. C. G.; MARTON E.; SOARES M. S.; JOURDAN, P. Caracterização do regime de vento em superfície na Região Metropolitana do Rio de Janeiro. Revista de Engenharia Sanitária e Ambiental, Rio de Janeiro, v. 19, n. 2, p. 121-132, 2014.

R Core Team (2015), R: A language and environment for statistical computing, R Foundation for Statistical Computing, Vienna, Austria, URL http://www,R-project,org/.

SOARES, M. S.; D’AIUTO, B. C.; PIMENTEL, L. C. G., PÉREZ GUERRERO, J. S., VICENTINI, P. C. Análise Comparativa da Concentração de Dióxido de Enxofre via Modelos Regulatórios AERMOD e 
CALPUFF e Monitoramento Próximo as Fontes de Emissão da Bacia Aérea III - RMRJ. Revista Brasileira de Meteorologia, Curitiba, v. 29, n.2, p.281-298, 2014.

WRPLOT View - Wind Rose Plots for Meteorological Data.

http://www.weblakes.com/products/wrplot/?AspxAutoDetectCookieSupport=1, (2015)

ZERI, M.; CARVALHO, V. S. B.; CUNHA-ZERI, G.; OLIVEIRA JÚNIOR, J. F.; LYRA, G. B.; FREITAS, E. D. Assessment of the variability of polluants concentration over the metropolitan area of São Paulo, Brazil, using the wavelet transform. Atmospheric Science Letter, Malden, v. 17, p. 87-95, 2016.

ZERI, M.; OLIVEIRA JÚNIOR, J. F.; LYRA, G. B. Spatiotemporal analysis of particulate matter, sulfur dioxide and carbon monoxide concentrations over the city of Rio de Janeiro, Brazil. Meteorology and Atmospheric Physics, Vienna, v. 113, n. 1, p. 139-152, 2011. 